\title{
ADDISON'S DISEASE AND RHEUMATOID ARTHRITIS
}

BY

\author{
C. E. G. ROBINSON \\ Vancouver, B.C.
}

(RECEIVED FOR PUBLICATION DECEMBER 10, 1956)

The association of rheumatoid arthritis and Addison's disease in the same patient is very rare. In the English literature three papers reporting single cases have been found, and reference was made in two of these to three French articles dealing with the same subject (Perera and Ragan, 1950; Caughey and McCoy, 1951; Ellman and Cudkowicz, 1952). In these cases the onset of rheumatoid arthritis preceded the development of Addison's disease.

Because of its rarity it is thought worthwhile to report another case which has been under our observation for 5 years. This man has rheumatoid spondylitis but no peripheral joint disease and, in fact, this form of rheumatoid disease occurring in association with Addison's disease has not previously been reported.

\section{Case Report}

A 50-year-old war veteran, who enlisted in 1939, was injured in a motorcycle accident during training in England in May, 1942. He had moderately severe head injuries with fractures of both frontal bones, and the left parietal and squamous temporal bones. He had a short period of retrograde amnesia and was described as being confused and antagonistic for 2 weeks after the injury.

Complete records of the clinical findings are not available, but $x$-rays of the spine are reported as showing fusion of both sacro-iliac joints and calcification of the paraspinal ligaments in the lumbar region. It is interesting that he had no complaints of back pain or sciatica then or previously.

He was returned to Canada and discharged from the army in August, 1942, with a diagnosis of concussion, post-traumatic syndrome, and rheumatoid spondylitis. His discharge medical board records a blood pressure of $120 / 80$. He stated that he was feeling generally well and, except for limited back bending, had no specific complaints.

During the next 2 years this man developed a variety of complaints, including nervousness and irritability, lack of vitality, fatiguability, gradual loss of $20 \mathrm{lb}$. in weight, loss of potency and later of libido, and pigmentations around the face, neck, and palmar creases. Until the latter developed he was diagnosed as psycho-neurotic by most observers.

In August, 1944, he developed a mild respiratory infection with cough and expectoration, together with anorexia and vomiting. On admission to hospital he was afebrile, and pigmentation was noted on the face, genitalia, and buccal mucosa.

Blood pressure, 90/40; haemoglobin, 77 per cent.; white blood cells, 4,850; erythrocyte sedimentation rate, $63 \mathrm{~mm}$. hr. (Westergren); serum $\mathrm{NaCl}, 480 \mathrm{mg}$. (normal 550-620). Chest and skull X-rays negative.

A diagnosis of Addison's disease was made, and he was given crude adrenocortical extract and intravenous saline and was eventually maintained on $1 \mathrm{ml}$. Eschatin (Connaught) and $3 \mathrm{~g}$. added salt per day. This therapy controlled the disease to some extent, though he con-? tinued to lose weight.

During the next 8 or 9 years he was given increasingly larger doses of adrenocortical extract, and then D.O.C.A. first by injection and later by implanted pellets.

He was admitted to hospital several times for minor respiratory or gastro-intestinal infections, which precipitated crises or near-crises. When cortisone became available he was given this medication, and he has been maintained on $20-25 \mathrm{mg}$. per day with some added salt. He has since been generally much improved and has been free from hypoadrenal crises.

The spine has all the clinical evidence of rheumatoid spondylitis, with a flat lumbar curve, spinal immobility, and almost negligible chest expansion. In the past few months he has complained of some cervical pain but objectively no change has developed. There has been no peripheral joint involvement at any time.

Other investigations over the years have shown the following:

1948: Oral glucose tolerance curve of $88,110,91,71$, 100 mg. per cent.

1952: Basal metabolic rate, 14 per cent. 24-hr urinary ketosteroids-3.1 mg. After a 24-hr 25-mg. ACTH intravenous drip, 6.5 mg.

The serum electrolytes on several occasions supported the diagnosis of Addison's disease.

Water excretion tests were attempted twice but were unsuccessful because of vomiting. 
Skull $x$-rays show a smaller than usual pituitary fossa but probably within normal limits.

Flat plates of the abdomen show some calcified mesenteric lymph nodes but no calcification of the adrenals.

Mantoux test positive.

In summary, this appears to be a case of Addison's disease due to primary adrenocortical disease. In addition this patient has well-marked clinical and radiological evidence of rheumatoid spondylitis the onset of which predated the adrenocortical deficiency.

\section{Discussion}

Painless, or nearly painless, rheumatoid spondylitis is not unknown but is uncommon. Patients with lumbar spine and sacro-iliac involvement, who have no pain or have forgotten their pain, are seen from time to time, but it is very rare to find such extensive involvement without pain.

As Kendall (1951) stated, the association of Addison's disease and rheumatoid arthritis is probably co-incidental.

Adrenal gland function, as measured in routine laboratory studies, usually appears to be normal in rheumatoid patients. Dobriner (1951) suggested, however, that there exists a basic imbalance in steroid production and/or metabolism resulting in an abnormal urinary excretion pattern. He presumed a decreased hormone production by the adrenal gland. In addition, a quantitative abnormality was found in four out of five patients studied who excreted a steroid, 17-hydroxy pregnenolone, that was not found in a study of thirty normal subjects. He concluded that both a quantitative and qualitative alteration of hormone production by the adrenal glands was involved in the aetiology of rheumatoid arthritis.

In a recent discussion of this subject, Holley (1956) points out that there is increasing evidence that the anterior pituitary may be implicated primarily. He quotes the findings of Pearse (1950) of a selective degranulation of the mucoid cells of the anterior pituitary in nine out of ten autopsied cases of rheumatoid disease and in one out of three cases of lupus erythematosus. These changes, which are similar to that seen in Addison's disease, were not found in two hundred controls. Further investigations will be necessary before the significance of minor pituitary and adrenal changes in the aetiology of rheumatoid disease can be more definitely evaluated.

\section{Summary}

(1) A case of rheumatoid spondylitis and Addison's disease in the same patient is presented.

(2) This is the fourth report of the association of rheumatoid arthritis and Addison's disease in the English literature. The previous three cases had peripheral joint involvement, but this case is the first with spondylitis and Addison's disease. In all four cases the onset of arthritis preceded the development of Addison's disease.

(3) Some of the literature pertaining to adrenal and pituitary function and possible dysfunction as related to rheumatoid disease is briefly discussed.

\section{REFERENCES}

Caughey, J. E., and McCoy, J. E. (1951). Brit. med. J., 2, 1189. Dobriner, K. (1951). Bull. rheum. Dis., 2, No. 3, p. 5.

Ellman, P., and Cudkowicz, L. (1952). Annals of the Rheumatic Diseases, 11, 225.

Holley, H. L. (1956). Ann. intern. Med., 45, 550.

Kendall, E. C. (1951). Brit. med. J., 2, 1295.

Pearse, A. G. E. (1950). Lancet, i, 954.

Perera, G. A., and Ragan, C. (1950). Proc. Soc. exp. Biol. (N.Y.) $75,99$.

La maladie d'Addison et l'arthrite rheumatismale RÉSUMÉ

(1) On décrit un cas de spondylite rhumatismale et de maladie d'Addison chez le même sujet.

(2) C'est le quatrième cas dans la littérature anglaise d'association de l'arthrite rhumatismale et de la maladie d'Addison. Les trois cas précédents présentèrent des implications articulaires périphériques. Celui-ci est le premier comportant la spondylite et la maladie d'Addison. Dans les quatre cas le début de l'arthrite précéda celui de la maladie d'Addison.

(3) On discute brièvement quelques-uns des articles se rapportant aux fonctions pituitaire et surrénale dans la maladie rhumatismale.

\section{La enfermedad de Addison y la artritis reumatoide} Sumario

(1) Se describe un caso de espondilartritis reumatoide y de enfermedad de Addison en el mismo sujeto.

(2) En la literatura inglesa ese es el cuarto caso de asociación de la artritis reumatoide con la enfermedad de Addison. Los tres casos anteriores presentaron implicaciones articulares periféricas; este caso es el primero comportando una espondilartritis y la enfermedad de Addison. En los cuatro casos el comienzo de la artritis, precedió el de la enfermedad de Addison.

(3) Se discuten brevemente algunos informes respecto a las funciones hipofisaria y suprarrenal en la enfermedad reumática. 